\title{
RELATIONSHIPS BETWEEN PERFORMANCE TEST RESULTS OF GILTS OF DIFFERENT BREEDS
}

\author{
Jerzy Nowachowicz, Grażyna Michalska, Tomasz Bucek, \\ Przemysław Dariusz Wasilewski \\ Department of Animal Products Evaluation, University of Technology and Life Sciences, \\ Ks. Kordeckiego 20, 85-225 Bydgoszcz, Poland
}

\begin{abstract}
The relationships expressed as calculated correlation coefficients were determined between the results of 44110 purebred gilts performance tested in the years 2004-2008. The animals came from the Bydgoszcz Breeding Region and represented 5 breeds (Polish Large White, Polish Landrace, Hampshire, Duroc and Pietrain) and synthetic Line 990. The traits taken into account were: age and body weight on test day, daily body weight gain standardized to 180 days of age, backfat thickness at $P_{2}$ and $P_{4}$ points, loin eye height at $P_{4}$ points, body meat content, and performance test selection index. Negative and highly significant correlations were found between growth rate and standardized backfat thickness at $P_{2}$ and $P_{4}$ points in all gilts of the tested breeds except Line 990. In the case of two breeds (Polish Large White and Pietrain) and Line 990, the correlation coefficients between daily body weight gain and standardized body meat content were negative and highly significant, which possibly suggests the unfavourable impact of high growth rate on the meat content. Higher correlation coefficient values were observed between the performance test selection index and the daily body weight gain than between the selection index and the body meat content of Polish Large White, Polish Landrace, Hampshire and Pietrain gilts.
\end{abstract}

Key words: pigs, gilts of different breeds, performance test, correlations

Productivity in terms of economically important traits, including the performance test traits of different breeds and lines of pigs reared in particular countries and regions is diversed and changes over the years (Bobček et al., 2002; Eckert and Szyndler-Nędza, 2005; Haferland, 1985; Michalska and Nowachowicz, 2002). It depends on many factors including genetic factors such as breed or line and gender of the pigs. The relationships occur among specific traits, the values of which vary according to the breed and gender of the pigs (Buczyński et al., 2001; Falkenberg et al., 1989; Michalska and Nowachowicz, 2002; Michalska et al., 2005, 2008). The 
genetic and phenotypic correlations provide information about them (Buczyński et al., 2001). The analysis of performance test results of the pigs in terms of the correlations occurring between particular traits of different breeds over the years makes it possible to estimate changes taking place in these populations. This information may be used in genetic breeding programmes for pigs.

The aim of the present paper was to determine the relationships between the results of gilts of different breeds, performance tested in the years 2004-2008 in the Bydgoszcz Breeding Region.

\section{Material and methods}

The analysis covered 44110 gilts representing the following 5 breeds: Polish Large White $(n=17284)$, Polish Landrace $(n=24381)$, Hampshire $(n=287)$, Duroc $(n=1224)$ and Pietrain $(n=534)$, and synthetic Line $990(n=400)$. The animals were performance tested according to the methodology employed in the years 2004-2008 (Eckert and Szyndler-Nędza, 2005). They came from the Bydgoszcz Breeding Region, which covers the Kujawsko-Pomorskie province. The performance test results of these animals were presented in another publication (Nowachowicz et al., 2010).

The analysis covered the following performance test traits, between which the relationships, expressed as calculated correlation coefficients, were determined:

- age on test day (days),

- body weight on test day $(\mathrm{kg})$,

- daily body weight gain standardized to 180 days of age $(\mathrm{g})$,

- standardized backfat thickness at the $\mathrm{P}_{2}$ point $(\mathrm{mm})$,

- standardized backfat thickness at the $\mathrm{P}_{4}$ point $(\mathrm{mm})$,

- standardized loin eye height at the $\mathrm{P}_{4}$ point $(\mathrm{mm})$,

- body meat percentage standardized to 180 days of age (\%),

- performance test selection index (points).

The results were analysed statistically by the computer program Statistica 8.0 (2008).

\section{Results}

The performance test selection index shows the breeding value in terms of growth and slaughter traits depending on daily body weight gain standardized to 180 days of age and body meat content estimated based on backfat thickness measurements at $\mathrm{P}_{2}$ and $\mathrm{P}_{4}$ points and loin eye height at $\mathrm{P}_{4}$ point. The discussion of the results was mainly focused on the relationships between the most important results of the performance 
test (growth rate, meat content and selection index) and the remaining results of this evaluation as well as the relationships among the three traits mentioned above. Table 1 gives the correlation coefficients between daily body weight gain and the remaining traits of gilts of the analysed breeds performance tested in the years studied. Negative and highly significant correlations between daily body weight gain and age on the performance test day were observed. Generally, positive and significant $(\mathrm{P} \leq 0.01)$ relationships between growth rate and body weight on the performance test day were found. This result was only different in Line 990, in which the correlation coefficient was $-0.159 * *$. Negative and highly significant correlations between daily body weight gain and standardized backfat thickness at $\mathrm{P}_{2}$ and $\mathrm{P}_{4}$ points were observed for Polish Large White, Polish Landrace, Hampshire, Duroc and Pietrain gilts. The correlation coefficients ranged from $\mathrm{r}=-0.158^{* *}$ in Duroc to $\mathrm{r}=-0.337 * *$ in Pietrain for $\mathrm{P}_{2}$ point and from $\mathrm{r}=-0.075 * *$ in Duroc to $\mathrm{r}=-0.264 * *$ in Hampshire for $\mathrm{P}_{4}$ point. The results were different in the gilts of Line 990, in which positive correlations were obtained $\left(0.178^{* *}\right.$ at $\mathrm{P}_{2}$ point and $0.179^{* *}$ at $\mathrm{P}_{4}$ point). Positive and highly significant correlation coefficients were noted between daily body weight gain and standardized loin eye height at $\mathrm{P}_{4}$ point. They ranged from $0.158^{* *}$ in Line 990 to $0.368^{* *}$ in Duroc. The relationships between growth rate and standardized body meat content of the tested gilts were negative and highly significant for Polish Large White, Pietrain and Line 990, and non-significant and close to 0 in the remaining three breeds (Polish Landrace, Hampshire and Duroc). In the gilts of the tested breeds, the daily body weight gain was positively and highly significantly correlated with the performance test selection index. The correlation coefficients were high $\left(>0.700^{* *}\right)$ except for the gilts of Line $990(\mathrm{r}=0.008)$.

Table 2 presents the correlation coefficients between the body meat content of gilts of the tested breeds and the remaining parameters of their performance test. The meat content of gilts was positively and highly significantly correlated with age and body weight on the performance test day. Negative and significant $(\mathrm{P} \leq 0.01)$ correlation coefficients were found between the gilts' body meat content and their fat content expressed as backfat thickness at $\mathrm{P}_{2}$ and $\mathrm{P}_{4}$ points. These correlations ranged from $\mathrm{r}=-0.196^{* *}$ in Pietrain to $\mathrm{r}=-0.647 * *$ in Line 990 for standardized backfat thickness at $\mathrm{P}_{2}$ points. Similar trends were also stated for standardized backfat thickness at $\mathrm{P}_{4}$ points (from $\mathrm{r}=-0.361 * *$ in Pietrain to $\mathrm{r}=-0.647 * *$ in Line 990). In Polish Large White, Polish Landrace, Hampshire and Duroc gilts, positive and highly significant correlations were found between the meat content and the standardized loin eye height at $\mathrm{P}_{4}\left(0.512^{* *}, 0.566^{* *}, 0.423^{* *}\right.$ and $0.444^{* * *}$, respectively). It should be noticed that a different trend was observed in Pietrain gilts, in which the correlation coefficient was negative $\left(-0.137^{* *}\right)$. Similar trends can be seen for gilts of Line $990(\mathrm{r}=-0.003)$. The body meat content of the tested gilts was positively and highly significantly correlated with the performance test selection index. The correlation coefficients were $0.280 * *$ (Pietrain), 0.582** (Polish Large White), 0.607** (Polish Landrace), 0.657** (Hampshire), 0.719** (Duroc) and $0.871 * *$ (Line 990). 

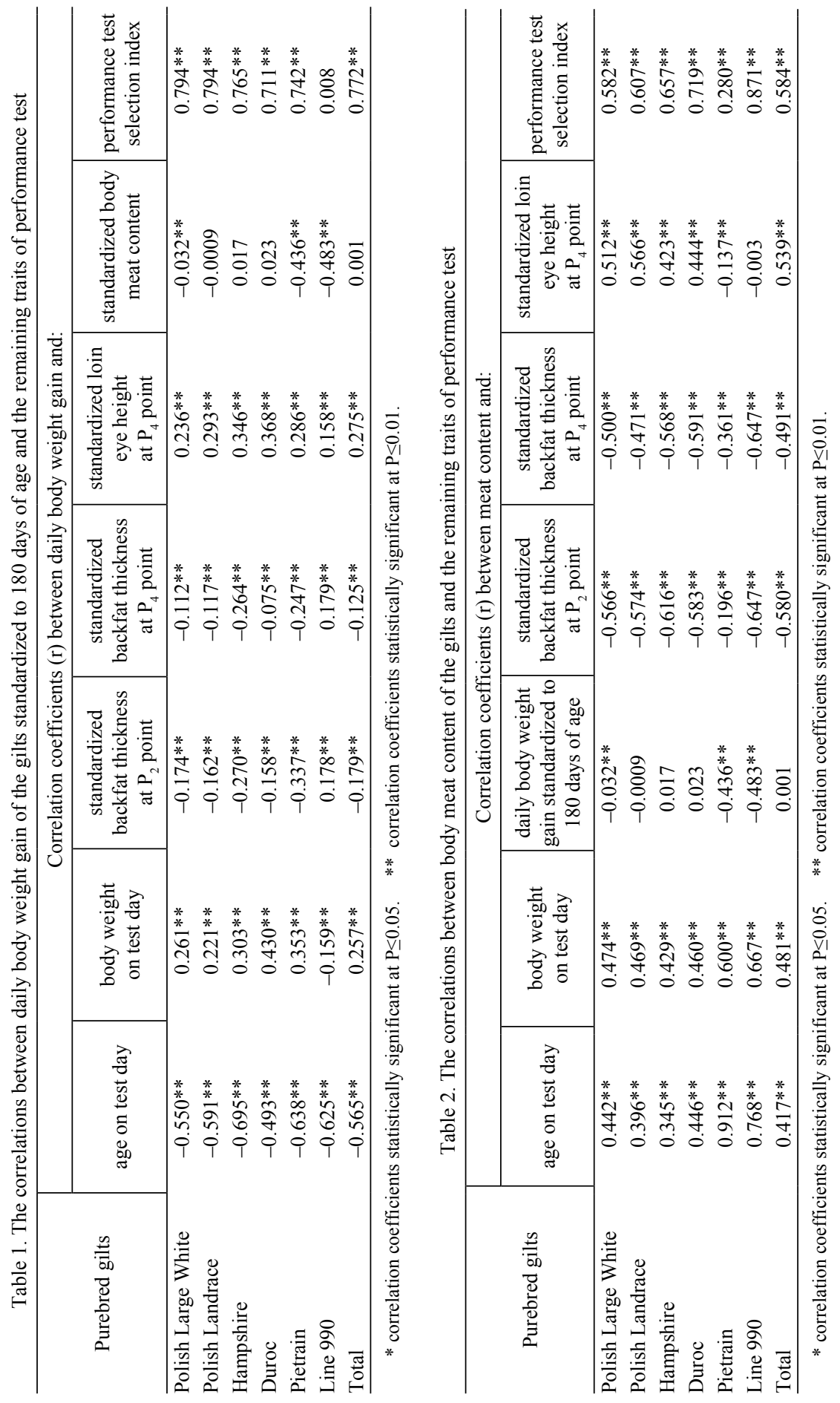


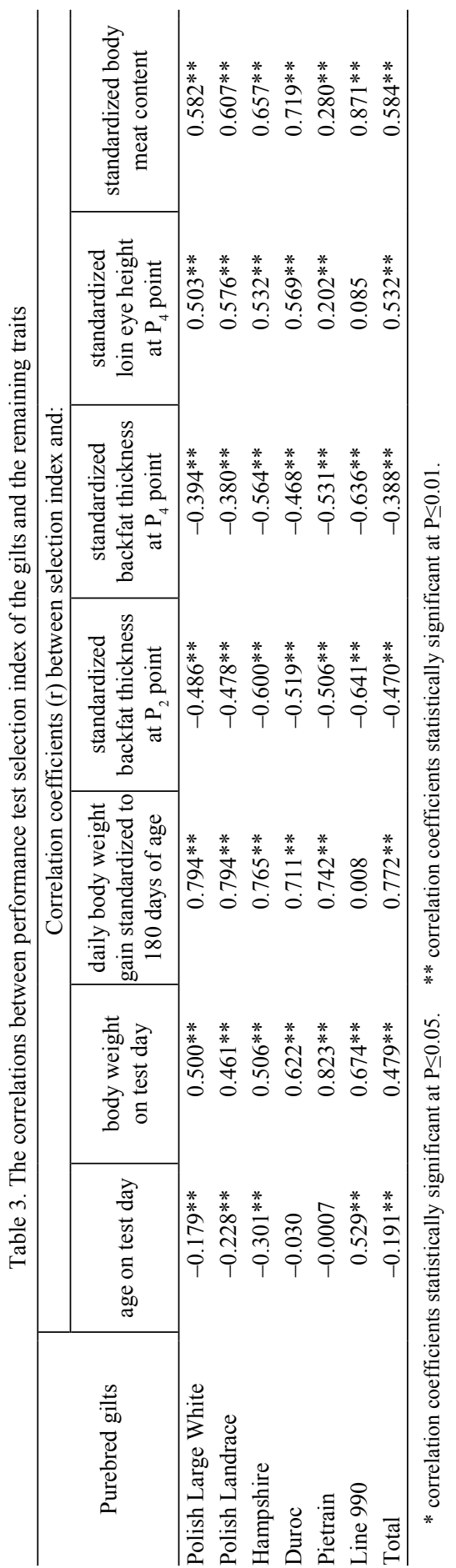


Table 3 shows correlation coefficients between the selection index and the remaining performance test traits. Negative relationships were found between the selection index and the age on test day (except Line 990 pigs). Positive and highly significant correlations were observed between the selection index and the body weight on test day (from $r=0.461^{* *}$ in Polish Landrace to $0.823^{* *}$ in Pietrain) and the growth rate. In this case, the correlation coefficients in Polish Large White, Polish Landrace, Hampshire, Duroc and Pietrain gilts were high and ranged from $r=0.711^{* *}$ (Duroc) to $r=0.794^{* *}$ (Polish Large White and Polish Landrace). The result obtained for animals of Line 990 differed considerably from the above mentioned breeds, with $r=0.008$. Negative and highly significant correlation coefficients between the selection index and backfat thickness measured at $\mathrm{P}_{2}$ and $\mathrm{P}_{4}$ points were found. In general, the performance test selection index was positively and highly significantly correlated with the standardized loin eye height at $\mathrm{P}_{4}$ point (except Line 990) and the standardized body meat content. The overall results for all tested gilts showed that the selection index was more correlated with the daily body weight gain $(\mathrm{r}=0.772 * *)$ than with the standardized body meat content $\left(r=0.584^{* *}\right)$. Regarding the results of the gilts of particular breeds, this trend is clearly seen in Polish Large White, Polish Landrace, Hampshire and Pietrain pigs, but different trends were found in the pigs of Line 990. In Duroc gilts, the relationship between the selection index and the growth rate and the meat content was almost at the same level $\left(\mathrm{r}=0.711^{* *}\right.$ and $\mathrm{r}=0.719^{* *}$, respectively).

\section{Discussion}

In gilts of the 5 tested breeds, i.e. Polish Large White, Polish Landrace, Hampshire, Duroc and Pietrain, negative and highly significant relationships were found between growth rate and standardized backfat thickness at $\mathrm{P}_{2}$ and $\mathrm{P}_{4}$ points, but these correlations were positive in the pigs of Line 990. In our previous studies (Michalska et al., 2005, 2008), the positive correlations were noted between growth rate and backfat thickness at $\mathrm{P}_{2}$ and $\mathrm{P}_{4}$ points in Polish Large White pigs and in Złotnicka Spotted $\times$ Pietrain hybrids performance tested in 1995-2004 according to the methodology used at that time. The negative and highly significant correlation coefficients found in Polish Large White, Pietrain and Line 990 gilts between the growth rate and the meat content do not confirm the generally accepted view that higher daily body weight gain results in higher meat content. They may prove the unfavourable impact of the growth rate on the meat content. This is consistent with studies by other authors (Buczyński et al., 2001; Cameron and Curran, 1995; Kanis, 1988) and our previous findings (Michalska and Nowachowicz, 2002; Michalska et al., 2005, 2008), which suggest that the high daily body weight gains (especially under ad libitum feeding) may adversely affect the slaughter value by increasing the fat content and decreasing the meat content of pigs. The negative correlations obtained between the growth rate and meat content show that it is necessary to modify the formula of breeding value index of particular breeds and lines of the gilts so that the high daily 
body weight gains, which have an unfavourable impact on the meat content, do not have a significant share in the value of the performance test selection index. A closer relationship was found between the performance test selection index and the daily body weight gain than between the selection index and the body meat content in the Polish Large White, Polish Landrace, Hampshire and Pietrain gilts. Such trends were also observed in our previous publications (Michalska and Nowachowicz, 2002; Michalska et al., 2005, 2008) concerning the pigs of different breeds performance tested according to the methodology applied in the years 1995-2004.

It should be mentioned that the tested animals represented the nucleus herd from the Bydgoszcz Breeding Region, which accounts for over $25 \%$ of the national nucleus herd of pigs. The present research concerned a very large population of animals (44 000 gilts) representing 5 breeds and 1 synthetic line. The number of animals may be representative for the national pig population. The relationships observed in our study may concern all the nucleus herds of pigs in Poland.

In summing up the results obtained, the negative and highly significant relationships between the growth rate and the meat content found in Polish Large White, Pietrain and Line 990 gilts do not confirm the generally accepted view that higher daily body weight gain results in higher meat content. They may prove the unfavourable impact of the high growth rate on the meat content. The negative correlations obtained between the growth rate and meat content show that it is necessary to modify the formula of breeding value index of particular breeds and lines of the gilts so that the high daily body weight gains, which have an unfavourable impact on the meat content, do not have a significant share in the value of the performance test selection index. Higher values of the correlation coefficients were obtained between the performance test selection index and the daily body weight gain than between the selection index and the body meat content in Polish Large White, Polish Landrace, Hampshire and Pietrain gilts.

\section{References}

B obč e k B., Ř e háč e k P., F la k P., K ováč L., Mly n e k J. (2002). Comparison of production traits of Large White and White Meaty pig breeds for 1996 to 2001 in Slovakia. Czech J. Anim. Sci., 47 (11): 451-459.

Buczyński J.T., Fajfer E., Panek A., S zulc K. (2001). Correlations between fattening and slaughter traits measured live after the first and second phase of rearing Polish Large White breeding gilts. Ann. Anim. Sci., Suppl., 1: 31-36.

C a m e r o n N.D., C u r r a n M.K. (1995). Genotype with feeding regime interaction in pigs divergently selected for components of efficient lean growth rate. Anim. Sci., 61: 123-132.

Eckert R., Szyndler-Nędza M. (2005). In vivo evaluation of young boars. In: The present breeding state and pig testing in the year 2004 (in Polish). Wyd. IZ PIB, Kraków, XXIII: 30-53.

Falkenberg H., Hammer H., Ritter E. (1989). Genetische und phenotypische Beziehungen zwischen Merkmalen der Mast- und Ansatzleistung von Ebern in zentralen Aufzuchtstationen, der Besamungseignung dieser Tiere sowie der Wurfleistung ihrer Schwestern. Arch. Tierz. Dummerstorf, 32 (2): 163-172.

H a ferland D. (1985). Untersuchungen zur Fruchtbarkeit bei Edelschwein unter den Bedingungen der industriemasigen Zuchtorganisation und Konsequenzen für die Selektion auf reproduktive Lebensleistung. Arch. Tierz. Dummerstorf, 28 (4): 339-345. 
Kan is E. (1988). Effect of average daily food intake on production performance in growing pigs. Anim. Prod., 46: 111-122.

Michalsk a G., N ow a chowi c z J. (2002). Correlations between selected traits of growing boars as evaluated in vivo (in Polish). Pr. Mat. Zoot., Zesz. Spec., 13: 99-107.

Michalska G., Nowachowicz J., B ucek T., W a silewski P.D. (2005). Relationships between performance test results of young crossbred boars with Zlotnicka Spotted and Pietrain breeding. Ann. Anim. Sci., Suppl., 1: 39-42.

Michalska G., Nowachowicz J., W a silewski P.D., B ucek T. (2008). Relationship between performance test results of young Polish Large White boars (in Polish). Rocz. Nauk. Zoot., $35,1: 53-61$.

Nowachowicz J., Michalska G., Bucek T., Wasilewski P.D. (2010). Changes in range of performance test results of purebred gilts produced in Bydgoszcz Breeding Region. Pig Meat. Modern trends in meat production. Polskie Towarzystwo Technologów Żywności, Oddział Małopolski, pp. 61-67.

Accepted for printing 21 VI 2011

\section{JERZY NOWACHOWICZ, GRAŻYNA MICHALSKA, TOMASZ BUCEK, PRZEMYSŁAW DARIUSZ WASILEWSKI}

\section{Zależności zachodzące między wynikami oceny przyżyciowej loszek różnych ras}

\section{STRESZCZENIE}

Określono zależności wyrażone w postaci obliczonych współczynników korelacji, zachodzące pomiędzy wynikami oceny przyżyciowej 44110 loszek czysto rasowych, przeprowadzonej w latach 2004-2008. Zwierzęta reprezentowały 5 ras: wielką białą polską, polską białą zwisłouchą, Hampshire, Duroc i Pietrain oraz syntetyczną linię 990. Pochodzily one z bydgoskiego okręgu hodowlanego. Branymi pod uwagę cechami były: wiek i masa ciała w dniu oceny, przyrost dobowy masy ciała standaryzowany na 180 . dzień życia, grubość słoniny w punktach $\mathrm{P}_{2}$ i $\mathrm{P}_{4}$, wysokość „oka” polędwicy w punkcie $\mathrm{P}_{4}$, zawartość mięsa $\mathrm{w}$ ciele oraz indeks selekcyjny oceny przyżyciowej. U loszek badanych ras, $\mathrm{z}$ wyjątkiem linii 990, stwierdzono ujemne i statystycznie wysoko istotne korelacje pomiędzy tempem wzrostu a standaryzowaną grubością słoniny w punktach $\mathrm{P}_{2}$ i $\mathrm{P}_{4}$.

W przypadku dwóch ras, tj. wielkiej białej polskiej i Pietrain oraz linii 990 współczynniki korelacji między przyrostem dobowym masy ciała a standaryzowaną zawartością mięsa w ciele były ujemne i statystycznie wysoko istotne, co może świadczyć o niekorzystnym wpływie wysokiego tempa wzrostu na mięsność. Stwierdzono większe wartości współczynników korelacji między indeksem selekcyjnym oceny przyżyciowej a przyrostem dobowym masy ciała, niż między indeksem selekcyjnym a zawartością mięsa w ciele loszek u ras wielkiej białej polskiej, polskiej białej zwisłouchej, Hampshire i Pietrain. 